\title{
ターチオフェン自己組織化単分子膜の構造
}

\author{
松浦俊彦・高村 工丂 $^{*} \cdot$ 下山雄平 \\ 北海道教育大学函館校物理学教室 雪 040-0083 北海道函館市八幡町 1-2 \\ *北海道立工業技術センター 041-0801 北海道函館市桔梗町 379
}

(1998 年 5 月 13 日受付；1998 年 7 月 8 日揭载決定)

\section{Structure of Self-Assembled Monolayers of Terthiophene}

Toshihiko MATsuUra, Takumi TAKAMURA and Yuhei ShIMOYAMA

Department of Physics, Hokkaido University of Education, 1-2 Hachiman-cho, Hakodate, Hokkaido 040-0083

${ }^{*}$ Hokkaido Industrial Technology Center, 397 Kikyo-cho, Hakodate, Hokkaido 041-0801

(Received May 13, 1998 ; Accepted July 8, 1998)

\begin{abstract}
Using X-ray diffraction and Fourier-transform infrared spectroscopy, we carried out a structure study of vacuum evaporated films and self-assembled monolayers (SAM) of terthiophene. It is shown with vacuum evaporated films that the long axis of terthiophene aligns normal to the surface. On the other hand, terthiophene in the SAM orients parallel to the gold substrate. Our results, which contradict the recent quantum chemical calculations predicting that thiophene would not interact with gold, experimentally demonstrated direct interaction between thiophene and gold.
\end{abstract}

\section{1.はじめに}

ポリチオフェンは五員環構造のチオフェンを単位とし た代表的な複素環高分子である。導電性を有し，光学特 性や機械特性にむ優れている”。新しい電界トランジス タや発光ダイオードなどの有機電子秦子に利用が考えら れている。また, 窒素酸化物 $\left(\mathrm{NO}_{\mathbf{x}}\right)$ 等の公害ガスのセ ンサとしての応用例もある。しかし，ポリチオフェンは 有機溶媒に不溶で分解温度まで加熱しても溶融しないた め, 薄膜作製が困難である。一方，オリゴチオフェンや ポリアルキルチオフェンは溶媒に可溶である。オリゴマ 一は明瞭な化学構造と共役鎖長を正確にコントロールで きるため, ポりチオフェンよりむ物性解析が容易である。 従来, チオフェン化合物の真空蒸着膜およびラングミュ アーブロジェット（Langmuir-Blodgett: LB）膜が報告され ている2 5)。しかしこれらの力法では安定な膜の作製 は容易ではない。

近年, 基板を溶液に浸漬することで, 自発的に単分子 膜を形成する自己組織化単分子膜（self-assembled mono-

E-mail: yuhei@hak.hokkyodai.ac.jp layer: SAM）法が発明されだ。本手法によって，きわ めて简単に安定な高密度・高配向単分子膜の形成が可能 となった。Au(111) 面上に形成されるアルカンチオー ル SAM は，容易さと実用性ゆえに多くの研究がある”。 チオール基（-SH）を有する分子が SAM を形成する要 因は，第 1 に水素原子の脱離による金と硫黄原子間の化 学結合，第 2 にアルキル鎖間の相互作用 (van der Waals 力）である。チオフェン化合物では, 金基板上にポリ(3アルキルチオフェン) のSAM 形成が報告されだ)。チ オフェン単量体でもSAM として形成可能であることが 走査型トンネル顕微鏡 (scanning tunneling microscope: STM）によって示された9)。よって，アルキル鎖を持た ないオリゴチオフェンむ金基板上に SAM を形成する可 能性があると考えられる。

本研究では, 3 つのチオフェン環からなり, 有機溶媒 に可溶なターチオフェンを用いて, 金基板上に SAMを 作製し, その構造を解析する。さらに, 真空蒸着膜の構 造との比較を武みる。

\section{2. 実 験 方 法}

膜物質は2, $2^{\prime}: 5^{\prime}, 2^{\prime \prime}$-terthiophene $\left(\mathrm{C}_{12} \mathrm{H}_{8} \mathrm{~S}_{3}:\right.$ 東京 
化成）を用いた。溶媒はエチルアルコール（スペクトル ダレード : キシダ化学)を, 金(田中貴金属)は純度 99.99 \%を使用した。基板は䉓子顕微鏡用の天然マイカ（俧研 商事）を使用した。

金基板は，スパッタリング法によってマイカ辟開面上 に厚さ約 $90 \mathrm{~nm}$ の金薄膜を作製し,さらに, 真空中で 500 ${ }^{\circ}$ Cの熱処理をした。ターチオフェン蒸着膜は抵抗加熱型 真空蒸着装置 (HUS-5 GB：日立)にて室温で成膜した。 SAM はターチオフェンのエチルアルコール溶波 $(1 \mathrm{mM})$ に，金基板を浸清させて成膜した。金基板を一昼夜浸滆 した後, エチルアルコールでリンスしたものを構造評洒 に用いた。
構造評価は, X線回折法（JDX-8020：JEOL）とフー リエ変換赤外分光法 (Fourier-transform infrared spectroscopy: FT-IR, Perkin-Elmer SYSTEM 2000）を使用 した。 比較のため, マイカおよびガラス基板上に成膜した真空 蒸着膜のX線回折を行った。FT-IRの分解能は $4 \mathrm{~cm}^{-1}$ で，2000 回のスキャンを積算してスペクトルを得た。 試料表面一の入射角は $85^{\circ}$ に設定し, 角度可変型反射率 測定装置を用いた。測定は室温で行い， $\mathrm{CO}_{2}$ や $\mathrm{H}_{2} \mathrm{O}$ の 影盤をできるだけ防ぐために $\mathrm{N}_{2}$ によるパージを行った。 これにより, 分光器中の $\mathrm{CO}_{2}$ や $\mathrm{H}_{2} \mathrm{O}$ などの吸収を大幅 に除去できた。本研究でのスペクトルは，試料と金清浄 表面のスペクトルの比である。FT-IR 测定は膜厚を考慮

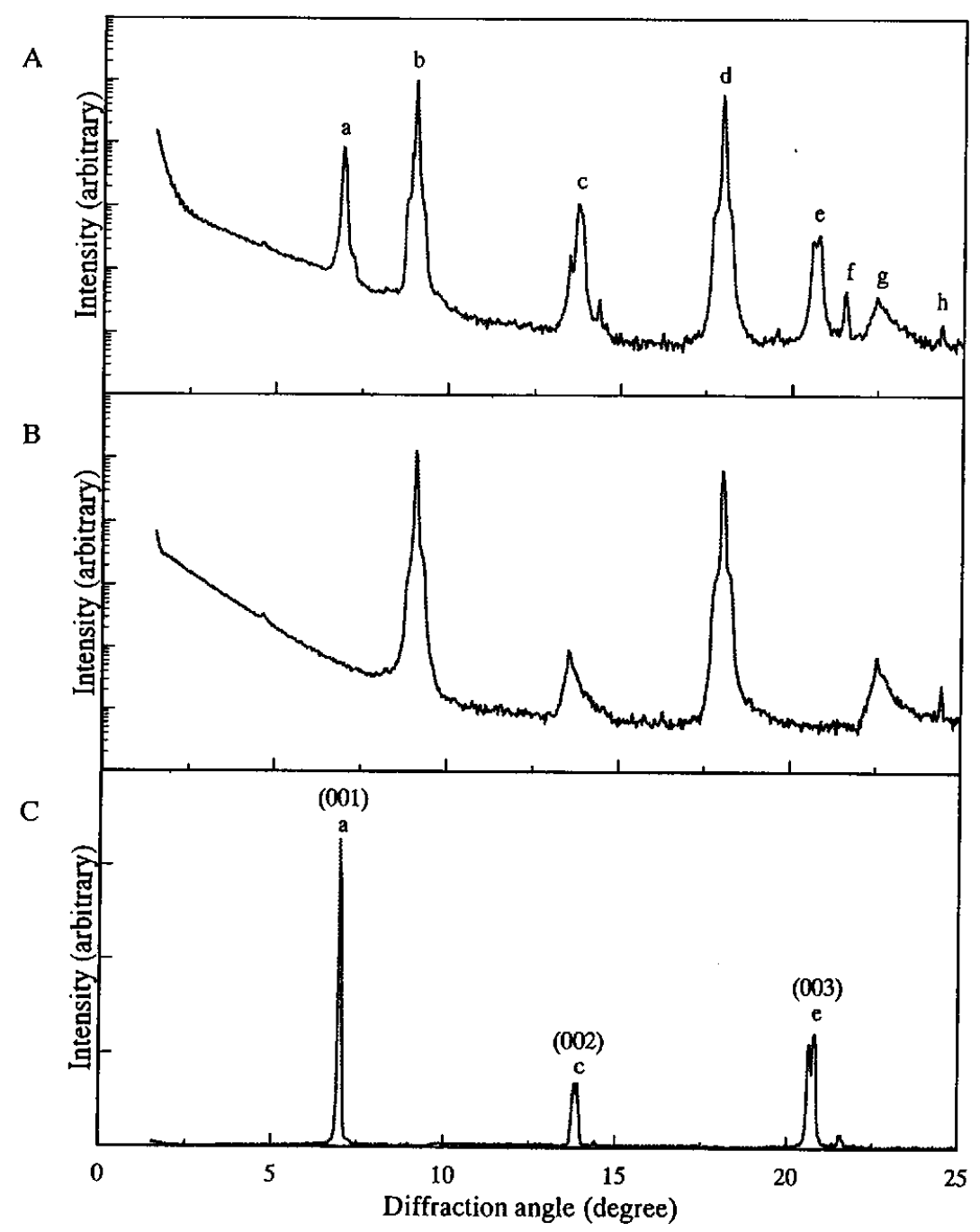

Fig. 1 X-ray diffraction patterns of A) vacuum evaporated films of terthiophene formed on gold substrate, B) pure gold substrate and C) the terthiophene as shown by an intensity ratio of $\mathbf{A} / \mathbf{B}$. 
して, 蒸着膜では偏光外部反射法, SAM では反射吸収 法を用いた。ターチオフェンには大別して 3 つ振動領 域がある。 $3070 \mathrm{~cm}^{-1}$ の C-H 伸縮振動, $1410 \mathrm{~cm}^{-1}$ の C: $\mathrm{C}$ 伸縮振動そして $680 \mathrm{~cm}^{-1}$ の-CH=CH-および-CH 面外変 角振動である。分子の長軸を $x$ 方向とすると, 以上 $3 つ$ の振動はそれぞれ $x, y, z$ の遙移モーメントに対応する。

\section{3. 結果}

\section{1 真空蒸着膜の分子配向}

Fig. 1-A と1-Bにそれぞれ金基板上に成膜したターチ オフェン蒸着膜と金基板のX線回折パターンを示す。 Fig. 1-C には蒸着膜の X 線回折パターンを金基板の回折
パターンで除算したものを示す。これにより, 蒸着膜に よる回折ビークを選択的に取り出すことができた。Fig. 1-A の a, c, e, f の各ピークは蒸着膜による回折であり, Fig. 1-Cにも観測される。b，d，g，hはマイカによる回 折である (Fig. 1-B参貿)。膜分子による鋭い回折ピー

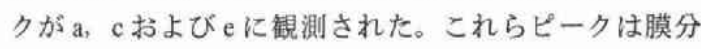
子の $(00 l)$ 面によるブラッグ反射である。回折強度は (001) 反射が最大で，高次反射は $l=2$ を除いて指数関 数的に低下する。このことより，基板の法線方向に周期 的秩序があることが示唆された ${ }^{10)}$ 。また，ガラスおよび マイカ基板上に成膜した蒸着膜でも同様の構造が観湘さ れた。

A

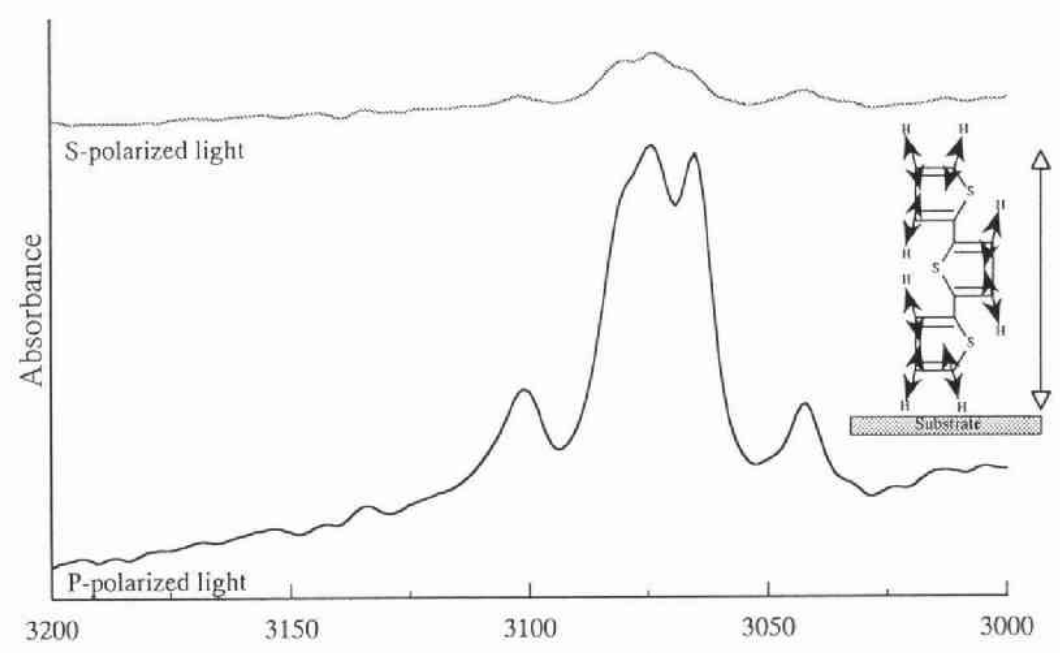

B

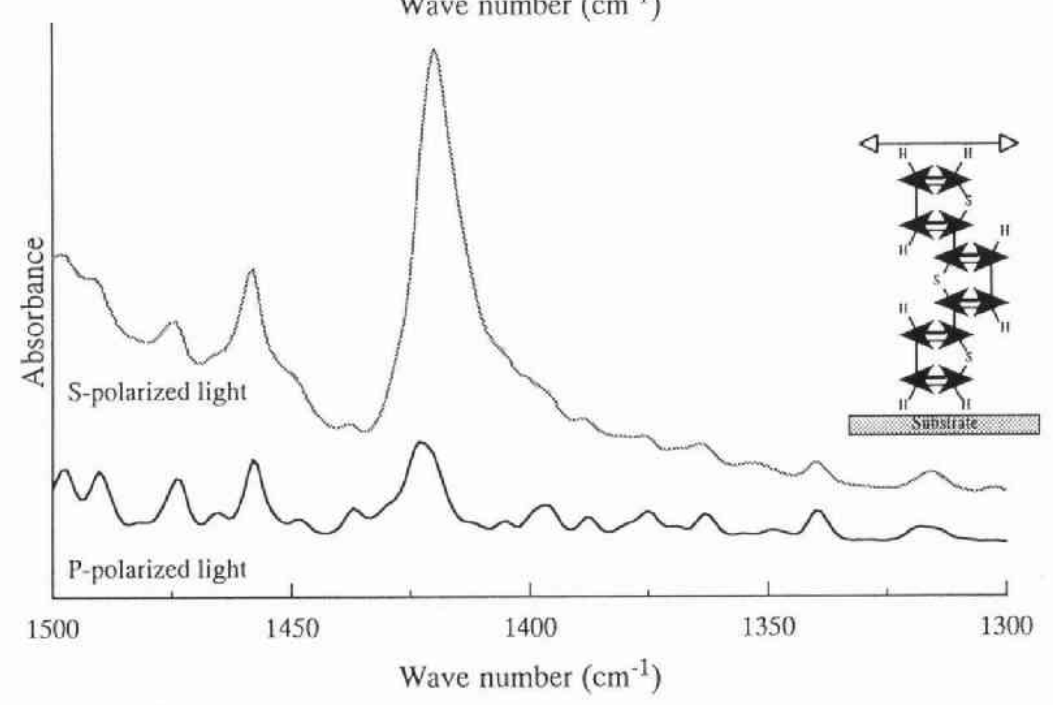

Fig. 2 FT-IR spectra of evaporated films of terthiophene formed on gold substrate. Spectra for A) $\mathrm{C}-\mathrm{H}$ stretching and $\mathrm{B}) \mathrm{C}=\mathrm{C}$ stretching vibration of thiophene ring are shown. 
Fig. 2 にターチオフェン蒸着膜の FT-IR 偏光外部反射 法による測定結果を示す。サンプルに $\mathrm{p}$ 偏光を入射した とき, チオフェン環の C-H間の伸縮振動による吸収を 示した (Fig. 2-A)。一方, s 偏光を入射したとき, C=C 間の伸縮振動による吸収を示した（Fig. 2-B）。p 偏光は 基板の法線方向, $\mathrm{s}$ 偏光は平行方向に電場が与えられる。 ゆえに，蒸着膜の分子はその長軸が金基板に垂直に配向 することが示された。この事実はX線回折の (001) 面 の面間隔がターチオフェン分子の分子長とほほ等しいこ とからも確認された。

\section{$3.2 \mathrm{SAM}$ の分子配向}

SAM の FT-IR 反射吸収測定ではターチオフェンがも つ3つの振動領域のちち, 面外変角振動のみが観測され た。Fig. 3 に SAM の $680 \mathrm{~cm}^{-1}$ 付近のスペクトルを示す。 面外変角振動の遷移モーメントは分子面に垂直 $(z$ 方向) である。反射吸収法において赤外光の電場が金基板の法 線方向であるから，ターチオフェン分子が金基板に平行 に配向していることがわかる。一方，分子面内方向の振
動である $3070 \mathrm{~cm}^{-1}$ と $1410 \mathrm{~cm}^{-1}$ 付近のピークは観測さ れなかった。振動の遷移モーメントが電場に垂直な場合, スペクトル強度は無視できるほど小さくなる。面内振動 は基板に平行であり,分子が基板に平行に配向している。 また，平面構造をなすターチオフェン分子がねじれを起 こさずに吸着することもわかる。これは面外振動の結果 と一致した。X 線回折では単分子層なので回折ビークは 観測されなかった。しかし，FT-IR の赤外吸収スペクト ルにより単分子膜の存在が示唆された。

\section{4. 考察}

\section{1 蒸着膜の分子配向}

X 線回折㧍よびFT-IRによって, 蒸着膜のターチオフ エン分子はその長軸が金基板に垂直に配向することがわ かった。石英ガラス基板上に成膜した quinquethiophene （チオフェン環が $5 つ ）$ 蒸着膜は分子長軸が基板の法線 方向に配向することが報告されている2)。チオフェン環 の数が異なるが, 分子配向は本研究の蒸着膜と一致する。

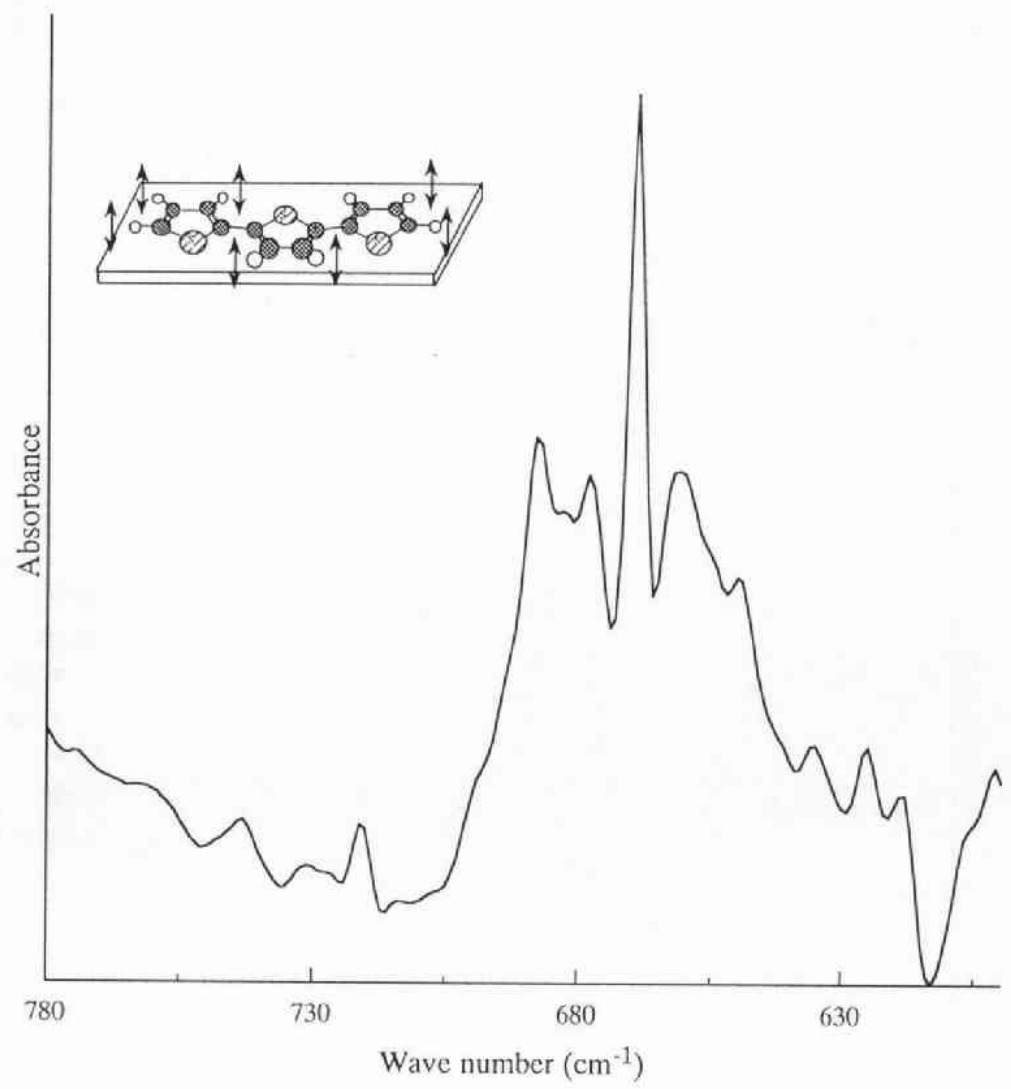

Fig. 3 An FT-IR spectrum of the self-assembled monolayers of terthiophene on gold substrate. The p-polarizing light with respect to the incident plane was applied to detect the out-of-plane $-\mathrm{CH}$ and $-\mathrm{CH}=\mathrm{CH}$ - vibrations. 
蒸着膜では分子配向は基板の種類や温度に依存する。夕 一チオフェン蒸着膜を室温で作製した場合, 分子配向は 基板による影響がない。このことは，分子間の凝集力が 強いためと考えられる。蒸発分子がどのように基板上に 飛来するが，物質や温度によって異なるが，複数分子 の集合体（クラスター）を成すと思われる。蒸発源から 基板までは自由空間であり, 分子間の相互作用（凝集エ ネルギー）のみが㖶くためである。ターチオフェンの場 合, クラスターは分子の $z$ 轴方向に平面を合わせた形で 成長する。共役系の平面性が共役分子間の相互作用を増 幅するからである。基板との結合エネルギーが小さいの で，表面拡散中に他のクラスターと衛突・結合しながら 成膜される。これが繰り返されるため基板の法線に周期 的秩序が形成されたと思われる。

\subsection{SAM の成膜と分子配向}

SAM 中では，分子は金基板に平行に配向している。 量子化学的にはチオフェン分子は金への吸着が不可能と されている ${ }^{11}$ 。しかし，本研究での FT-IR の結果はチ才 フェンが明らかに金基板に吸着することを示している。

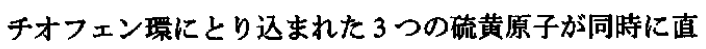
接金基板に吸着する。これが,ターチオフェン分子が金 基板に平行に配向する原因であろ5。SAM と蒸着膜の 成膜過程の相違点は分子をランダムに分散させる溶媒効 果と思われる。分子がクラスターを形成せず個別に直接 基板まで飛来し，単分子での表面应散を行い易くする。 エチルアルコールも金基板表面の脱水, 脱ガスそして脱 不純物の促進㓮として働く。これらも分子配向を決める 要因であろう。

SAM の形成過程は分子の飛来, 吸着, 拡散, 脱離, 核形成そして 2 次元膜化である。SAM の主な形成要因 は有機分子が持つ官能基による基板原子との化学吸着, そして有機分子間の相互作用（van der Waals 力および静 電気力）である6。 過程を経て SAM を形成する。しかし，タ一チオフェン は安定な成膜に約 24 時間むかかり，アルカンチオール に比べて長時間である。poly (3-octylthiophene) の場合

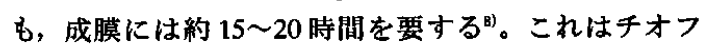
エンと金基板の相互作用が弱いためと思われる。ターチ オフェンの吸着は化学反応である可能性は小さい。なぜ なら化学吸着では分子の变形（例えば解麈）を伴う。金 原子と反応可能なアルカンチオールとは違って，チオフ エン環は比較的不活性で分子変形や五貝環の解裂は難し い。よってチオフェン化合物による金基板上での自己組 織化には時間がかかる。また, ターチオフェンにはアル キル鎖がなく主鎖以外の分子間力が小さいため, アルキ
ルチオフェンよりも成膜に時間がかかると思われる。

Elfeninat らは理論のみならず, 実験においてもチオフ エンが金に吸着しないことを示した"1)。しかし，その実 験的根拠は poly (3-hexylthiophene) の薄膜の XPS 測定で ある。ポリアルキルチオフェンは有機溶媒に可溶である など物理化学的性質が通常のポリチオフェンとはかなり 異なる。薄膜作製手法も異なる。よって本研究および通 常のポリチオフェンとの単純な比較はできない。FT-IR によって金基板に吸䍰するポリ(3-アルキルチオフェン) のSAM が確認された8)。STMによって，チオフェン単 量体のSAM も報告されている”。本研究はこれらの報 告を支持するものであり,アルキル鎖を持たないオリゴ チオフェンでむ金基板上に SAM を形成することが明瞭 に示された。

\section{5. 結}

金基板上に成膜したターチオフェンの真空蒸着膜と SAM の膜構造をX線回折および FT-IRにより評価し た。蒸着膜ではターチオフェン分子は金基板に垂直に配 向するのに対し,SAM では膜分子は金基板に平行配向 する。この結果より量子化学的に疑問視されていたチ才 フェン化合物の金への吸着を実験的に証明した。

\section{文姑}

1) 吉野勝美 : “分子とエレクトロニクス” (産業図畵, 1991).

2) Y. Kanemitsu, K. Suzuki, N. Shimizu, Y. Shiraishi and M. Kuroda: Jpn. J. Appl. Phys. 35, 1097 (1996).

3) H. Nakahara, J. Nakayama, M. Hoshino and K. Fukuda: Thin Solid Films 160, 87 (1988).

4) S. Tasaka, H.E. Katz, R.S. Hutton, J. Orenstein, G.H. Fredrickson and T.T. Wang: Synthetic Metals 16, 17 (1986).

5) P.B. Logsdon, J. Peleger and P.N. Prasad: Synthetic Metals 26, 369 (1988).

6) A. Ulman: "An Introduction to Ultrathin Organic Films from Langmuir-Blodgett to Self-Assembly" (Academic Press, Boston, 1991).

7) P. Fenter, A. Eberhardt and P. Eisenberger: Science 266, 1216 (1994).

8) Z. Gao, K.S. Siow and H.S.O. Chan: Synthetic Metals 75, 5 (1995).

9) M.H. Dishner, J.C. Hemminger and F.J. Feher: Langmuir 12, 6176 (1996).

10) T. Takamura, K. Matsushita and Y. Shimoyama: Jpn. J. Appl. Phys. 35, 5831 (1996).

11) F. Elfeninat, C. Fredriksson, E. Sacher and A. Selmani: J. Chem. Phys. 102, 6153 (1995). 